\title{
Pengaruh Senam Yoga terhadap Kualitas Tidur dan Fungsi Kognitif pada Lansia
}

\author{
Auditya Agnesia, ${ }^{1}$ Damajanty H. C. Pangemanan, ${ }^{2}$ Hedison Polii ${ }^{2}$
}

\author{
${ }^{1}$ Program Studi Pendidikan Dokter Fakultas Kedokteran Universitas Sam Ratulangi \\ Manado, Indonesia \\ ${ }^{2}$ Bagian Fisiologi Fakultas Kedokteran Universitas Sam Ratulangi Manado, Indonesia \\ Email: auditya.agnesia789@gmail.com
}

\begin{abstract}
An Elderly is someone who has reached the age of 60 years or more. The number of elderly in Indonesia in 2020 has reached 28.7 million. This number continues to increase every year. The elderly will naturally experience changes both physically and mentally which can reduce their quality of life. The quality of sleep and cognitive function in the elderly also changes due to aging factors. The purpose of this study was to determine the effect of yoga exercises on sleep quality and cognitive function in the elderly. This research is a literature review. This study studied topics related to the effect of yoga exercises on sleep quality and cognitive function in the elderly from previous studies. The literature reviewed consists of 15 literature with 8 literature discussing the effect of yoga exercises on sleep quality in the elderly and 7 other literature discussed the effect of yoga exercise on cognitive function in the elderly. The results of this study indicate that yoga exercises that are carried out regularly both in the long and short term can improve the quality of sleep in the elderly and maintain cognitive function in the elderly. It can also prevent dementia and Alzheimer's disease in the elderly.

Keywords: yoga exercise, sleep quality, cognitive function, elderly
\end{abstract}

\begin{abstract}
Abstrak: Lansia merupakan seseorang yang sudah mencapai usia 60 tahun atau lebih. Jumlah lansia di Indonesia pada tahun 2020 mencapai 28,7 juta jiwa. Angka ini terus meningkat tiap tahunnya. Lansia secara alamiah akan mengalami perubahan baik secara fisik dan mental yang dapat menurunkan kualitas hidupnya. Kualitas tidur dan fungsi kognitif pada lansia juga mengalami perubahan akibat faktor penuaan. Tujuan dari penelitian ini adalah untuk mengetahui pengaruh senam yoga terhadap kualitas tidur dan fungsi kognitif pada lansia. Penelitian ini merupakan penelitian yang sifatnya literature review. Penelitian ini mempelajari topik-topik terkait pengaruh senam yoga terhadap kualitas tidur dan fungsi kognitif pada lansia dari penelitian-penelitiam sebelumnya. Literatur yang diulas dan dipelajari sebanyak 15 literatur dengan 8 literatur membahas pengaruh senam yoga terhadap kualitas tidur pada lansia dan 7 literatur lainnya mengulas pengaruh senam yoga terhadap fungsi kognitif pada lansia. Hasil penelitian ini menunjukkan bahwa senam yoga yang dilakukan secara rutin baik dalam jangka panjang maupun pendek dapat memperbaiki dan meningkatkan kualitas tidur lansia. Senam yoga juga dapat mempertahankan fungsi kognitif lansia dan mencegah lansia dari penyakit demensia dan alzheimer.
\end{abstract}

Kata kunci : senam yoga, kualitas tidur, fungsi kognitif, lansia

\section{PENDAHULUAN}

Populasi lansia mengalami peningkatan baik di negara maju maupun negara berkembang yang disebabkan oleh penurunan angka natalitas dan mortalitas, serta peningkatan angka harapan hidup yang mengubah struktur penduduk secara keseluruhan. ${ }^{1}$ Jumlah lansia di Indonesia pada tahun 2020 mencapai 28,7 juta jiwa. ${ }^{1}$ Angka ini terus meningkat tiap tahunnya.

Lansia mengalami perubahan yang sangat menonjol pada pola tidur-bangunnya 
yaitu terjadi pengurangan pada gelombang lambat, terutama stadium 4 non-rapid eye movement, gelombang alfa menurun, dan meningkatnya frekuensi terbangun di malam hari atau meningkatnya fragmentasi tidur karena seringnya terbangun. ${ }^{2}$ Seringnya terbangun pada malam hari membuat lansia mudah mengantuk, sulit konsentrasi, dan mudah letih sehingga dapat menyebabkan penurunan kualitas hidup.

Hal lain yang dapat menurunkan kualitas hidup adalah penurunan fungsi kognitif. Lansia dapat mengalami perubahan baik secara biologis, psikologis, dan sosial sehingga dapat mengganggu kehidupan sehari-hari mereka. ${ }^{3}$ Penurunan fungsi kognitif dapat dihambat dengan melakukan tindakan preventif. Salah satu tindakan preventif yang dapat dilakukan lansia yaitu dengan melakukan aktivitas fisik. $^{4}$

Aktivitas fisik adalah gerakan tubuh oleh otot tubuh dan sistem penunjangnya yang menyebabkan peningkatan energi., ${ }^{5,6}$ Salah satu aktivitas fisik yang dapat dilakukan oleh lansia adalah senam yoga. Yoga merupakan bentuk latihan yang memadukan gerak dan olah nafas ${ }^{7}$. Yoga dipercaya mampu menyegarkan dan menyejukkan pikiran, tubuh, dan jiwa juga dapat mengatasi kelainan fisik dan mental. ${ }^{8}$ Senam yoga dapat menstimulasi sekresi $\beta$ endorfin. ${ }^{9}$ Peningkatan $\beta$ - endorfin terbukti berhubungan erat dengan penurunan rasa nyeri, peningkatan daya ingat, memperbaiki nafsu makan, kemampuan seksual, tekanan darah, dan pernafasan. ${ }^{10}$

\section{METODE PENELITIAN}

Penelitian ini dilakukan pada bulan November-Desember 2020 di perpustakaan virtual. Jenis penelitian ini menggunakan metode studi pustaka (literature review) yang bersumber dari jurnal dan publikasi hasil studi pendahuluan terkait pengaruh senam yoga terhadap kualitas tidur dan fungsi kognitif pada lansia. Populasi dalam penelitian ini ialah seluruh jurnal dan artikel yang diperoleh dari Pubmed, Clinical Key, Sciencedirect, Google scholar, dan Perpustakaan Nasional RI dalam bentuk elektronik. Kriteria inklusi responden dalam pustaka ialah lansia,judul pustaka relevan dengan judul penelitian yakni pengaruh senam yoga terhadap kualitas tidur dan fungsi kognitif pada lansia, tahun publikasi pustaka 2011-2020, serta berbahasa Indonesia dan Inggris. Pustaka yang tidak tersedia full-text akan dieksklusi dan tidak terhitung sebagai sampel penelitian.

\section{HASIL PENELITIAN}

Data penelitian ini diperoleh dari Pubmed, Clinical Key, Sciencedirect, Google scholar, dan Perpustakaan Nasional RI dalam bentuk elektronik. Penulis mendapatkan 15 literatur yang telah melalui proses reduksi data sesuai dengan kriteria inklusi dan analisis yang terdiri dari 8 literatur yang membahas pengaruh yoga terhadap kualitas tidur pada lansia dan 7 literatur yang mengulas pengaruh yoga terhadap fungsi kognitif pada lansia; di antaranya 10 jurnal dari luar negeri dan 5 jurnal dari Indonesia. Tabel 1 memperlihatkan karakteristik 15 literatur tersebut.

Tabel 2 menunjukkan distribusi hasil uji statistik masing-masing literatur yang membahas pengaruh yoga terhadap kualitas tidur pada lansia dengan delapan literatur menunjukkan hasil yang signifikan. Enam literatur yang telah diulas menggunakan PSQI (Pittsburgh sleep quality index) sebagai instrumen pengumpulan data dan dua literatur lainnya menggunakan Insomnia rating scale. PSQI merupakan kuisioner yang berisi 19 pertanyaan mengenai tujuh aspek penilaian tidur yaitu subjective sleep quality, sleep latency, sleep duration, habitual sleep efficiency, sleep disturbance, use of sleeping medication, dan daytime dysfunction dengan penilaian skor 0-3 dimana skor 0 menunjukkan tidak ada gangguan. ${ }^{14}$ Dua diantara delapan literatur yang menggunakan PSQI menunjukkan secara detail penilaian tujuh aspek penilaian tidur.

Penelitian oleh Varsha yang dilakukan di India pada tahun 2018 menunjukkan 
enam aspek tidur yang memiliki nilai $\mathrm{p}<0,05$ dan aspek sleep duration menunjukkan nilai $\mathrm{p}=0,217$ sedangkan penelitian oleh Bankar yang dilakukan di India pada tahun 2013 menunjukkan lima aspek tidur yang memiliki nilai $\mathrm{p}<0,05$, aspek sleep duration dengan nilai $\mathrm{p}=$ 0,1293, dan aspek day disturbance dengan nilai $\mathrm{p}=0,2041$.

Tabel 3 menunjukkan distribusi hasil uji statistik masing-masing literatur yang membahas pengaruh yoga terhadap fungsi kognitif pada lansia dengan tujuh literatur menunjukkan hasil yang signifikan. Tujuh literatur mengulas pengaruh senam yoga terhadap fungsi kognitif dengan hasil yang signifikan yaitu nilai $\mathrm{p}<0,05$. Dua dari literatur tersebut mengulas mengenai pengaruh yoga terhadap salah satu bagian pada otak.

Penelitian yang dilakukan oleh Afonso di Brazil pada tahun 2017 mengulas pengaruh senam yoga terhadap ketebalan kortikal dengan nilai $\mathrm{p}<0,05$. Penelitian oleh Hariprasad yang dilakukan di India pada tahun 2013 membahas pengaruh yoga terhadap volume hipokampus dengan hasil yang signifikan yaitu terdapat peningkatan volume hipokampus bilateral dengan peningkatan hipokampus kiri $\mathrm{p}=0,01$ dan peningkatan hipokampus kanan $p=0,03$.

Tabel 1. Karakteristik pustaka

\begin{tabular}{|c|c|c|c|c|c|}
\hline No & $\begin{array}{l}\text { Peneliti/ } \\
\text { Tahun }\end{array}$ & $\begin{array}{c}\text { Lokasi } \\
\text { Penelitian }\end{array}$ & $\begin{array}{c}\text { Jenis } \\
\text { Penelitian }\end{array}$ & $\begin{array}{c}\text { Usia } \\
\text { Sampel } \\
\text { (Tahun) }\end{array}$ & Tujuan Penelitian \\
\hline 12 & $\begin{array}{l}\text { W Sisilia } \mathrm{dkk}^{9} \\
2019\end{array}$ & $\begin{array}{l}\text { Sural } \\
\text { Indor }\end{array}$ & $\begin{array}{l}\text { Pra eksperi- } \\
\text { mental }\end{array}$ & $60-74$ & 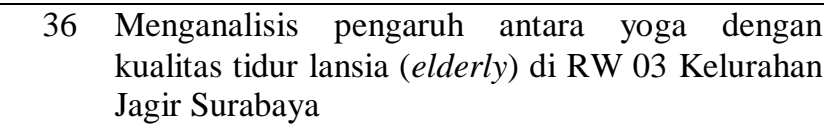 \\
\hline & $\begin{array}{l}\text { Gudawati } \\
\text { dkk }^{11} \\
2011\end{array}$ & $\begin{array}{l}\text { Karang- } \\
\text { anyar, } \\
\text { Indonesia }\end{array}$ & i- & $\begin{array}{l}60-74 \\
\text { dan } \\
>74\end{array}$ & $\begin{array}{l}51 \text { Mengetahui perbedaan tingkat insomnia lansia } \\
\mathrm{L}=10 \text { sebelum dan sesudah latihan senam yoga di } \\
\mathrm{P}=41 \text { Posyandu Lansia Desa Blulukan, Kecamatan } \\
\text { Colomadu, Kabupaten Karanganyar }\end{array}$ \\
\hline 35 & $\begin{array}{l}\text { Suhesti S dkk } \\
2014\end{array}$ & $\begin{array}{l}\text { Yog } \\
\text { Indo }\end{array}$ & speri- & $60-80$ & $\begin{array}{c}11 \text { Mengetahui pengaruh terapi yoga terhadap tingkat } \\
\mathrm{L}=4 \text { insomnia pada lansia di UPT Panti Wredha Budhi } \\
\mathrm{P}=7 \text { Dharma Ponggalan Umbulharjo Yogyakarta }\end{array}$ \\
\hline & $\begin{array}{l}\text { Grace dkk }{ }^{12} \\
2020\end{array}$ & $\begin{array}{l}\text { Sura } \\
\text { Indo }\end{array}$ & speri- & $60-85$ & $\begin{array}{cl}38 & \text { Mengetahui perbedaan kualitas tidur sebelum } \\
\mathrm{L}=1 & \text { sesudah senam yoga pada lansia di Posy } \\
\mathrm{P}=37 & \text { Lansia Yuswo Widodo Surabaya }\end{array}$ \\
\hline $5 \mathrm{H}$ & $\begin{array}{l}\text { Bankar dkk }{ }^{13} \\
2013\end{array}$ & $\begin{array}{l}\text { Nagpur, } \\
\text { India }\end{array}$ & is & $>60$ & $\begin{array}{l}65 \text { Mengevaluasi pengaruh latihan Yoga jangka } \\
\mathrm{L}=43 \text { panjang terhadap kualitas tidur dan kualitas hidup } \\
\mathrm{P}=22 \text { (QOL) pada lansia }\end{array}$ \\
\hline 6 & $\begin{array}{l}\text { Varsha }^{14} \\
2018\end{array}$ & Iru, & $\begin{array}{l}\text { Cross } \\
\text { sectional }\end{array}$ & $>60$ & $\begin{array}{l}\text { lai pengaruh latihan yoga jangka panjang } \\
\text { dap kualitas tidur }\end{array}$ \\
\hline $7 \mathrm{H}$ & $\begin{array}{l}\text { Hedge dkk } \\
2017\end{array}$ & $\begin{array}{l}\text { Banga } \\
\text { India }\end{array}$ & $\begin{array}{l}\text { Singl } \\
\text { pilot }\end{array}$ & $65-80$ & $\begin{array}{l}28 \text { Mengevaluasi pengaruh yoga selama satu bulan } \\
\mathrm{L}=13 \text { terhadap variabel jantung, kualitas tidur, kesehatan } \\
\mathrm{P}=15 \text { mental, dan kualitas hidup pada lansia yang } \\
\text { menderita penyakit kronis }\end{array}$ \\
\hline $8 \mathrm{r}$ & $\begin{array}{l}\text { Kennedy dkk } \\
2016\end{array}$ & $\begin{array}{l}\text { Melb } \\
\text { Austr }\end{array}$ & $\begin{array}{l}\text { Non } \\
\text { randomized } \\
\text { control trial }\end{array}$ & $>60$ & $\begin{array}{l}90 \text { Menguji keberhasilan intervensi yoga untuk } \\
\mathrm{L}=16 \text { pengobatan } \\
\mathrm{P}=74 \text { insomnia pada orang dewasa yang lebih tua }\end{array}$ \\
\hline 9 & $\begin{array}{l}\text { Vaezi dkk }{ }^{17} \\
2020\end{array}$ & Yazd, Iran & $\begin{array}{l}\text { Randomized } \\
\text { control trial }\end{array}$ & $>60$ & $\begin{array}{l}58 \text { Mengetahui pengaruh latihan yoga terhadap } \\
\mathrm{L}=0 \text { memori wanita lanjut usia } \\
\mathrm{P}=58\end{array}$ \\
\hline & $\begin{array}{l}\text { Hishikawa } \\
\text { dkk }^{18} \\
2019\end{array}$ & $\begin{array}{l}\text { Okay } \\
\text { Jepa }\end{array}$ & ksperi- & $\begin{array}{c}75,5 \pm 8 \\
7\end{array}$ & $\begin{array}{l}385 \text { Mengetahui efektivitas olahraga campuran dan } \\
\mathrm{L}=72 \text { yoga untuk kognitif, afektif, aktivitas kehidupan } \\
\mathrm{P}=313 \text { sehari-hari (ADL), dan fungsi fisik pada lansia. }\end{array}$ \\
\hline
\end{tabular}




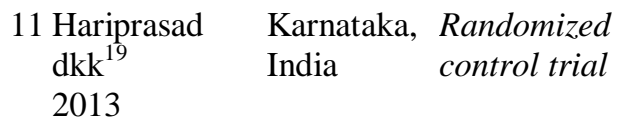
$\mathrm{dkk}^{20}$ 2014

13 Yanti dkk ${ }^{21}$ 2016

Denpasar, Pra eksperiIndonesia mental

14 Afonso dkk ${ }^{22}$ Sao Paulo, Cross 2017 Brazil sectional

15 Hariprasad $\mathrm{dkk}^{23}$ 2013
$>6087$ Mengetahui pengaruh intervensi berbasis yoga $\mathrm{L}=15$ dibandingkan dengan kelompok kontrol daftar $\mathrm{P}=72$ tunggu pada fungsi kognitif pada penghuni panti jompo

60-80 48 Menguji pengaruh trataka terhadap fungsi kognitif pada lansia

60-90 12 Mengetahui pengaruh Dharmagita terhadap fungsi $\mathrm{L}=8$ kognitif lansia

$\mathrm{P}=4$

$>6021$ Membandingkan ketebalan kortikal otak pada $\mathrm{L}=0$ kelompok praktisi yoga lansia dan kelompok non$\mathrm{P}=21$ praktisi lansia

69-81 7 Mengetahui pengaruh latihan yoga terhadap $\mathrm{L}=4$ volume hipokampus pada lansia yang sehat $\mathrm{P}=3$

Tabel 2. Distribusi hasil uji statistik pengaruh yoga terhadap kualitas tidur pada lansia masing-masing literatur

\begin{tabular}{|c|c|c|c|c|c|c|}
\hline No & Peneliti & $\begin{array}{l}\text { Instrumen } \\
\text { Penelitian }\end{array}$ & Protokol Yoga & $\begin{array}{l}\text { Intervensi } \\
\text { Grup } \\
\text { Kontrol }\end{array}$ & $\begin{array}{c}\text { Uji Statistik } \\
p \text {-value }\end{array}$ & Outcome \\
\hline 1 & $\begin{array}{l}\text { W Sisilia } \\
\mathrm{dkk}^{9}\end{array}$ & $\begin{array}{l}\text { Pittsburgh } \\
\text { sleep } \\
\text { quality } \\
\text { index }\end{array}$ & Tidak disebutkan & $\begin{array}{c}\text { Tidak } \\
\text { disebutkan }\end{array}$ & $\begin{array}{l}\text { Wilcoxon } \\
0,000\end{array}$ & $\begin{array}{l}\text { Lebih dari } 50 \%(66,6 \%) \text { kualitas } \\
\text { tidur buruk sebelum diberikan yoga } \\
\text { dan sebagian besar }(77,7 \%) \text { kualitas } \\
\text { tidur baik sesudah diberikan yoga }\end{array}$ \\
\hline 2 & $\begin{array}{l}\text { Gudawati } \\
\mathrm{dkk}^{11}\end{array}$ & $\begin{array}{l}\text { Insomnia } \\
\text { rating } \\
\text { scale }\end{array}$ & $\begin{array}{l}\text { Intervensi yoga } \\
\text { selama tujuh hari }\end{array}$ & $\begin{array}{l}\text { Pretest- } \\
\text { postest } \\
\text { one } \\
\text { group }\end{array}$ & $\begin{array}{c}\text { Paired } \\
\text { t-test } \\
0,001\end{array}$ & $\begin{array}{l}\text { Sebelum diberikan senam yoga } \\
\text { diperoleh nilai rata-rata } 18,45 \\
\text { (insomnia berat), setelah diberikan } \\
\text { senam yoga selama } 1 \text { minggu } \\
\text { terdapat penurunan nilai rata-rata } \\
\text { yaitu sebesar } 14,70\end{array}$ \\
\hline 3 & $\begin{array}{l}\text { Suhesti S } \\
\mathrm{dkk}^{8}\end{array}$ & $\begin{array}{l}\text { Insomnia } \\
\text { rating } \\
\text { scale }\end{array}$ & $\begin{array}{l}\text { Intervensi yoga } \\
\text { selama tujuh hari }\end{array}$ & $\begin{array}{l}\text { Pretest- } \\
\text { postest } \\
\text { one } \\
\text { group }\end{array}$ & $\begin{array}{l}\text { Wilcoxon } \\
0,003\end{array}$ & $\begin{array}{l}\text { Sebelum diberikan terapi yoga, } \\
\text { tingkat insomnia ringan } 1 \text { orang } \\
(9 \%) \text {, insomnia sedang } 9 \text { orang } \\
(82 \%) \text {, dan insomnia berat } 1 \text { orang } \\
(9 \%) \text { dan setelah diberikan terapi } \\
\text { yoga sebagian besar responden } \\
\text { mengalami penurunan tingkat } \\
\text { insomnia dengan insomnia ringan } 10 \\
\text { orang (91\%) dan } 1 \text { orang (9\%) tidak } \\
\text { mengalami penurunan }\end{array}$ \\
\hline 4 & $\begin{array}{l}\text { Grace } \\
\mathrm{dkk}^{12}\end{array}$ & $\begin{array}{l}\text { Pittsburgh } \\
\text { sleep } \\
\text { quality } \\
\text { index }\end{array}$ & $\begin{array}{l}\text { Intervensi yoga } \\
\text { selama delapan } \\
\text { minggu }\end{array}$ & $\begin{array}{l}\text { Pretest- } \\
\text { postest } \\
\text { one } \\
\text { group }\end{array}$ & $\begin{array}{l}\text { Wilcoxon } \\
0,000\end{array}$ & $\begin{array}{l}\text { Sebelum diberikan senam yoga } \\
\text { responden yang memiliki kualitas } \\
\text { tidur yang buruk }(55,3 \%) \text { dan } \\
\text { kualitas tidur yang baik }(7,9 \%) \text {, } \\
\text { setelah diberikan senam yoga } \\
\text { terdapat peningkatan kualitas tidur } \\
\text { yang baik }(47,4 \%)\end{array}$ \\
\hline 5 & $\begin{array}{l}\text { Bankar } \\
\mathrm{dkk}^{13}\end{array}$ & $\begin{array}{l}\text { Pittsburgh } \\
\text { sleep } \\
\text { quality } \\
\text { index }\end{array}$ & $\begin{array}{l}\text { Melakukan yoga } \\
\text { selama dua tahun } \\
\text { atau lebih dan } \\
\text { latihan yoga setiap } \\
\text { hari minimal satu } \\
\text { jam/hari }\end{array}$ & $\begin{array}{l}\text { Yoga dan } \\
\text { non-yoga }\end{array}$ & $\begin{array}{l}\text { Mann- } \\
\text { Whitney } \\
0,0001\end{array}$ & $\begin{array}{l}\text { Pada kelompok yoga nilai PSQI total } \\
\text { yaitu } 3,771 \pm 0,3623 \text { dan pada } \\
\text { kelompok non yoga yaitu } 8 \pm 0,4315\end{array}$ \\
\hline
\end{tabular}




\begin{tabular}{|c|c|c|c|c|c|c|}
\hline & $\operatorname{Varsha}^{14}$ & $\begin{array}{l}\text { Pittsburgh } \\
\text { sleep } \\
\text { quality } \\
\text { index }\end{array}$ & $\begin{array}{l}\text { Melakukan selama } \\
\text { dua tahun atau lebih } \\
\text { dan latihan yoga } \\
\text { setiap hari minimal } \\
\text { satu jam/hari }\end{array}$ & $\begin{array}{l}\text { Yoga dan } \\
\text { non-yoga }\end{array}$ & $\begin{array}{c}\text { Paired } \\
t \text {-test } \\
0,002\end{array}$ & $\begin{array}{l}\text { Pada kelompok yoga nilai PSQI total } \\
\text { yaitu } 3,2 \pm 0,918 \text { dan pada kelompok } \\
\text { non yoga yaitu } 7,9 \pm 0,99\end{array}$ \\
\hline & $\begin{array}{l}\text { Hedge } \\
\mathrm{dkk}^{15}\end{array}$ & $\begin{array}{l}\text { Pittsburgh } \\
\text { sleep } \\
\text { quality } \\
\text { index }\end{array}$ & $\begin{array}{l}\text { Intervensi yoga } \\
\text { selama satu bulan } \\
\text { dan dilakukan } \\
\text { selama } 60 \text { menit dari } \\
\text { jam 6-7 pagi setiap } \\
\text { enam hari selama } \\
\text { satu minggu }\end{array}$ & $\begin{array}{l}\text { Pretest- } \\
\text { postest } \\
\text { one } \\
\text { group }\end{array}$ & $\begin{array}{c}\text { Wilcoxon } \\
\text { dan Paired } \\
t \text {-test } \\
0,001\end{array}$ & $\begin{array}{l}\text { Sebelum diberikan yoga nilai da } \\
\text { PSQI adalah mean } 6,43 \pm 3,66 \text { da } \\
\text { setelah diberikan intervensi yog } \\
\text { mengalami penurunan yaitu mec } \\
2,86 \pm 1,86\end{array}$ \\
\hline & $\begin{array}{l}\text { Kennedy } \\
\mathrm{dkk}^{16}\end{array}$ & $\begin{array}{l}\text { Pittsburgh } \\
\text { sleep } \\
\text { quality } \\
\text { index }\end{array}$ & $\begin{array}{l}\text { Intervensi yoga dua } \\
\text { kali seminggu dalam } i \\
12 \text { minggu }\end{array}$ & $\begin{array}{l}\text { Yoga } \\
\text { intervention } \\
\quad \text { dan } \\
\text { waiting-list } \\
\text { control }\end{array}$ & $\begin{array}{l}\text { Anova } \\
<0,001\end{array}$ & $\begin{array}{l}\text { Pada kelompok yoga denga } \\
\text { kepatuhan tinggi, nilai PSQI sebelu } \\
\text { diberikan intervensi yoga mea } \\
10,26 \pm 3,14 \text { dan setelah melakuka } \\
\text { yoga mengalami penurunan yai } \\
\text { mean } 7,96 \pm 3,22\end{array}$ \\
\hline
\end{tabular}

Tabel 3. Distribusi hasil uji statistik pengaruh yoga terhadap fungsi kognitif pada lansia masing-masing literatur

\begin{tabular}{|c|c|c|c|c|c|c|}
\hline No & Peneliti & Protokol Yoga & $\begin{array}{l}\text { Intervensi } \\
\text { Grup } \\
\text { Kontrol }\end{array}$ & $\begin{array}{c}\mathrm{Uji} \\
\text { statistik }\end{array}$ & Variabel Kognitif & Outcome \\
\hline 1 & Vaezi dkk ${ }^{17}$ & $\begin{array}{l}\text { Intervensi yoga } \\
\text { selama delapan } \\
\text { minggu dengan } \\
\text { sesi tiga kali } \\
\text { satu jam dalam } \\
\text { satu minggu }\end{array}$ & $\begin{array}{l}\text { Intervention } \\
\text { dan Control }\end{array}$ & $\begin{array}{l}\text { Wilcoxon } \\
\text { dan } \\
\text { Paired } t- \\
\text { test }\end{array}$ & $\begin{array}{l}\text { Personal } \\
\text { awareness, } \\
\text { orientation, mental } \\
\text { control, logical } \\
\text { memory, repeating } \\
\text { figures, visual } \\
\text { memory, associative } \\
\text { learning, memory) }\end{array}$ & $\begin{array}{l}\text { Variabel mental control, } \\
\text { logical memory, visual } \\
\text { memory, dan memory } \\
\text { memiliki nilai } \mathrm{p}<0,005\end{array}$ \\
\hline 2 & $\begin{array}{l}\text { Bankar } \\
\mathrm{dkk}^{13}\end{array}$ & $\begin{array}{l}\text { Melakukan yoga } \\
\text { selama dua } \\
\text { tahun atau lebih } \\
\text { dan latihan yoga } \\
\text { setiap hari } \\
\text { minimal satu } \\
\text { jam/hari }\end{array}$ & $\begin{array}{c}\text { Yoga dan } \\
\text { non-yoga }\end{array}$ & $\begin{array}{l}\text { Mann } \\
\text { Whitney }\end{array}$ & $\begin{array}{l}\text { Cognitive } \\
\text { functioning scale } \\
\text { menggunakan } \\
\text { instrumen } Q O L \\
\text { Leiden-Padua } \\
\text { (LEIPAD) }\end{array}$ & $\begin{array}{l}\text { Pada kelompok yoga nilai } \\
\text { cognitive function pada } \\
\text { LEIPAD didapati mean } \\
1,647 \pm 0,3678 \text { dan pada } \\
\text { kelompok non yoga yaitu } \\
\text { mean } 3,2 \pm 0,4969 \text {. } \\
\text { Didapati nilai p cognitive } \\
\text { function pada LEIPAD } \\
\text { adalah } \mathrm{p}=0,0042\end{array}$ \\
\hline 3 & $\begin{array}{l}\text { Hariprasad } \\
\text { dkk }^{19}\end{array}$ & $\begin{array}{l}\text { Intervensi yoga } \\
\text { selama enam } \\
\text { bulan dengan } \\
\text { bulan pertama } \\
60 \text { menit setiap } \\
\text { hari, 2bulan } \\
\text { berikutnya satu } \\
\text { jam setiap } \\
\text { minggu, dan tiga } \\
\text { bulan berikutnya } \\
\text { berlatih di } \\
\text { rumah sendiri }\end{array}$ & $\begin{array}{l}\text { Yoga dan } \\
\text { wait-list }\end{array}$ & $\begin{array}{l}\text { Paired } t- \\
\text { test }\end{array}$ & $\begin{array}{l}\text { COWA, RAVLT: } \\
\text { total score, average } \\
\text { score, immediate } \\
\text { recall and delayed } \\
\text { recall; CFT: } \\
\text { Immediate and } \\
\text { delayed recall; } \\
\text { spatial span- } \\
\text { forward and } \\
\text { backward, Stroop } \\
\text { interference; TMT- } \\
\text { A and TMT-B }\end{array}$ & $\begin{array}{l}\text { Pada kelompok yoga } \\
\text { terdapat penaikan secara } \\
\text { signifikan selama } 6 \text { bulan } \\
\text { pada COWA, RAVLT: } \\
\text { Total score, immediate } \\
\text { recall and delayed recall; } \\
\text { CFT: Immediate and } \\
\text { delayed recall; spatial } \\
\text { span-forward and } \\
\text { backward, Stroop } \\
\text { interference and TMT-A }\end{array}$ \\
\hline 4 & $\begin{array}{l}\text { Jagannathan } \\
\mathrm{dkk}^{20}\end{array}$ & $\begin{array}{l}\text { Intervensi yoga } \\
\text { trataka selama } \\
\text { satu bulan }\end{array}$ & $\begin{array}{l}\text { Trataka dan } \\
\text { wait-list }\end{array}$ & $\begin{array}{l}\text { Friedman } \\
\text { dan } \\
\text { Wilcoxon }\end{array}$ & $\begin{array}{l}\text { Digit span test, } \\
S L C T \text { dan } T M T-B\end{array}$ & $\begin{array}{l}\text { Intervensi trataka selama } \\
\text { satu bulan menunjukkan } \\
\text { hasil yang signifikan pada } \\
\text { skor SLCT dan TMT-B } \\
(\mathrm{p}<0,01)\end{array}$ \\
\hline
\end{tabular}




\begin{tabular}{|c|c|c|c|c|c|c|}
\hline 5 & Yanti dkk ${ }^{21}$ & $\begin{array}{l}\text { Intervensi yoga } \\
\text { teknik } \\
\text { dharmagita } \\
\text { selama lima } \\
\text { minggu dengan } \\
\text { durasi } 60 \text { menit } \\
\text { satu kali } \\
\text { seminggu }\end{array}$ & $\begin{array}{l}\text { Pretest- } \\
\text { postest one } \\
\text { group }\end{array}$ & $\begin{array}{l}\text { Paired } t- \\
\text { test }\end{array}$ & MMSE score & $\begin{array}{l}\text { Sebelum diberikan } \\
\text { dharmagita skor MMSE } \\
\text { adalah mean } 23,92 \text { dengan } \\
\text { skor terendah } 19 \text { dan skor } \\
\text { tertinggi } 29 \text { dan setelah } \\
\text { diberikah dharmagita } \\
\text { mengalami peningkatan } \\
\text { yaitu mean } 25(\mathrm{p}=0,001)\end{array}$ \\
\hline 6 & $\begin{array}{l}\text { Afonso } \\
\mathrm{dkk}^{22}\end{array}$ & $\begin{array}{l}\text { Melakukan yoga } \\
\text { hatha minimal } 8 \\
\text { tahun }\end{array}$ & $\begin{array}{l}\text { Yoga dan } \\
\text { kontrol }\end{array}$ & $\begin{array}{l}\text { Independ } \\
\text { ent } t \text {-test }\end{array}$ & Ketebalan kortikal & $\begin{array}{l}\text { Kelompok yoga } \\
\text { menunjukkan CT yang } \\
\text { lebih besar secara } \\
\text { signifikan pada kluster } \\
\text { lobus prefrontal kiri } \\
(\mathrm{p}=0,01574)\end{array}$ \\
\hline 7 & $\begin{array}{l}\text { Hariprasad } \\
\mathrm{dkk}^{23}\end{array}$ & $\begin{array}{l}\text { Intervensi yoga } \\
\text { selama } 6 \text { bulan }\end{array}$ & $\begin{array}{l}\text { Pretest- } \\
\text { postest one } \\
\text { group }\end{array}$ & $\begin{array}{l}\text { Paired } t- \\
\text { test }\end{array}$ & $\begin{array}{l}\text { Volume } \\
\text { hipokampus }\end{array}$ & $\begin{array}{l}\text { Terdapat peningkatan } \\
\text { yang signifikan pada } \\
\text { volume hipokampus } \\
\text { bilateral dengan } \\
\text { peningkatan hipokampus } \\
\text { kiri } \mathrm{p}=0,01 \text { dan } \\
\text { peningkatan hipokampus } \\
\text { kanan } \mathrm{p}=0,03\end{array}$ \\
\hline
\end{tabular}

\section{BAHASAN}

\section{Pengaruh yoga terhadap kualitas tidur pada lansia}

Berdasarkan dua literatur yang memperlihatkan hasil yang detail dari kuisioner PSQI, terdapat dua aspek yang menunjukkan hasil yang tidak signifikan. Penelitian yang dilakukan oleh Varsha di India tahun 2018 dan Bankar di India tahun 2013 menunjukkan aspek sleep duration yang tidak signifikan. Penurunan durasi tidur pada lansia dapat disebabkan oleh faktor ketuaan. Lansia umumnya tidur sekitar 6-7 jam sehari karena adanya penurunan fase NREM 4 aktivitas gelombang delta menurun atau hilang, hal ini membuat tidur lansia menjadi lebih singkat atau berkurang dibandingkan dengan orang dewasa yang rata-rata 8 jam sehari $^{24}$. Aspek daytime dysfunction pada penelitian oleh Bankar yang dilakukan di India pada tahun 2013 menghasilkan nilai $p$ yang tidak signifikan dikarenakan durasi tidur yang pendek pada lansia dapat menyebabkan lansia mudah mengantuk di siang hari sehingga mengalami gangguan seperti sulit konsentrasi dalam menjalankan aktivitasnya.

Enam literatur yang menggunakan PSQI menunjukkan hasil yang signifikan dengan nilai $\mathrm{p}<0,05$ pada PSQI total walaupun terdapat dua aspek dengan hasil tidak signifikan. Penelitian yang dilakukan oleh Gudawati di Indonesia pada tahun 2011 dan Suhesti di Indonesia tahun 2014 menggunakan Insomnia rating scale sebagai instrumen penelitian juga menunjukkan hasil yang signifikan terhadap lansia yang mengalami insomnia terbukti karena adanya penurunan tingkat insomnia yang signifikan dengan nilai $\mathrm{p}<0,05$. Insomnia pada lansia sering terjadi akibat terganggunya fase tidur NREM stadium 45 . Hal lain yang dapat mempengaruhi insomnia pada lansia adalah stres. Senam yoga dapat membantu dalam mengatasi stres dan insomnia. Melakukan senam yoga dapat menstimulasi $\beta$-endorfin yang merupakan neurotransmitter tidur dan juga menenangkan.

Penelitian yang dilakukan Bankar di India tahun 2013 dan Varsha di India tahun 2018 memperlihatkan perbedaan nilai total PSQI yang sangat besar antara kelompok yoga yang telah melakukan yoga selama minimal 2 tahun lebih dan kelompok yang tidak pernah melakukan yoga. Kedua hasil penelitian menunjukkan perbedaan angka yang cukup besar pada nilai total PSQI yaitu 4-5 antara dua kelompok tersebut. 
Berdasarkan delapan literatur yang telah diulas maka peneliti dapat menyimpulkan bahwa lansia yang melakukan senam yoga secara rutin dalam jangka panjang dapat mengalami perbaikan dan peningkatan kualitas tidur.

\section{Pengaruh yoga terhadap fungsi kognitif pada lansia}

Berdasarkan tujuh literatur yang mengulas pengaruh yoga terhadap fungsi kognitif, masing-masing literatur memiliki instrumen penilaian sendiri terkait aspekaspek kognitif yang diteliti. Aspek kognitif yang diulas pada lima literatur diatas ratarata menunjukkan pengaruh yoga terhadap memori lansia, baik itu memori jangka panjang, jangka pendek, dan memori sesaat. Tujuh literatur tersebut menghasilkan nilai $\mathrm{p}<0,05$ yang menandakan bahwa terdapat hasil yang signifikan pada ketujuh literatur tersebut.

Dua penelitian membahas mengenai pengaruh yoga terhadap salah satu bagian otak dimana penelitian ini dapat menjadi bukti kuat adanya pengaruh yoga terhadap fungsi kognitif pada lansia. Penelitian yang dilakukan Afonso di Brazil pada tahun 2017 mengulas pengaruh yoga terhadap ketebalan kortikal pada sampel yang telah melakukan yoga selama minimal delapan tahun. Ketebalan kortikal dapat dihubungkan dengan fungsi kognitif dikarenakan kortikal merupakan area penting dalam memori kerja dan fungsi eksekutif, hipokampus, dan memori ${ }^{26}$. Pada penelitian ini, Afonso juga mengemukakan bahwa dengan melakukan senam yoga secara rutin, lansia dapat mempertahankan fungsi kognitifnya dan dapat terhindar dari penyakit demensia.

Penelitian yang dilakukan Hariprasad di India pada tahun 2013 mengulas pengaruh yoga terhadap bagian otak yang lain yaitu Hipokampus pada sampel yang diberikan intervensi yoga selama enam bulan. Pada penelitian yang dilakukan oleh Hariprasad, terdapat peningkatan volume terhadap kedua hipokampus, yaitu hipokampus kanan dan hipokampus kiri. Hipokampus merupakan materi abu-abu yang rentan mengalami penurunan akibat faktor penuaan. Penurunan volume hipokampus dapat menjadi indikator awal dari penyakit demensia dan alzheimer ${ }^{23}$.

Literatur yang telah diulas membuktikan bahwa senam yoga secara rutin dalam jangka panjang dapat mempertahankan fungsi kognitif pada lansia dan dapat mencegah lansia dari penyakit demensia dan alzheimer yang dapat mengganggu kelangsungan hidup lansia.

\section{SIMPULAN}

Berdasarkan penelitian yang dilakukan maka dapat disimpulkan bahwa senam yoga yang dilakukan secara rutin baik dalam jangka panjang maupun pendek dapat memperbaiki dan meningkatkan kualitas tidur lansia selain itu senam yoga juga dapat mempertahankan fungsi kognitif lansia dan mencegah lansia dari penyakit demensia dan alzheimer.

\section{Konflik Kepentingan}

Penulis menyatakan tidak terdapat konflik kepentingan dalam studi ini.

\section{DAFTAR PUSTAKA}

1. Kementerian Kesehatan RI. Situasi Lansia di Indonesia tahun 2017. Pusat Data dan Informasi. Published online 2017:1-2.

2. Amir N. Gangguan Tidur pada Lanjut Usia Diagnosis dan Penatalaksaan. Cermin Dunia Kedokteran. 2007;157:199.

3. Theresa RM, Trihandini I. Hubungan Antara Fungsi Kognitif dengan Tingkat Kemandirian dan Kualitas Hidup Warga Usia Lanjut. Bina Widya. 2013;24(3):139.

4. Sauliyusta M, Rekawati E. Aktivitas Fisik Memengaruhi Fungsi

Kognitif Lansia. Jurnal Keperawatan Indonesia. 2016;19(2):72.

5. Sholihin AD, Sugiarto. Analisis Aktivitas Fisik dan Aktivitas Belajar pada Mahasiswa Fakultas Ilmu Keolahragaan Universitas 
Negeri Semarang dalam Memanfaatkan Waktu Luang. Journal of Sport Sciences and Fitness. 2015;4(4):35.

6. Sudibjo P, Arovah NI, Ambardini RL. Tingkat Pemahaman dan Survei Level Aktivitas Fisik, Status Kecukupan Energi dan Status Antropometrik Mahasiswa Program Studi Pendidikan Kepelatihan Olahraga FIK UNY. Medikora. 2013;11(2):185.

7. Sukartini T, Indarwati R. Latihan Yoga dapat Memenuhi Kebutuhan Tidur Lansia (Yoga Exercise Fulfillment of the Sleep Needs in Elderly). Journal Ners. 2008;3(2):158.

8. Suhesti, Suratini. Pengaruh Terapi Yoga terhadap Tingkat Insomnia pada Lansia Di UPT Panti Wredha Budhi Dharma Ponggalan Umbulharjo Yogyakarta. Published online 2014:1.

9. Indriasari S, Putra RA. Pengaruh Yoga Terhadap Kualitas Tidur Lansia (Elderly). Jurnal Keterapian Fisik. 2019;4(2):78-84.

10. Dinata WW. Menurunkan Tekanan Darah pada Lansia melalui Senam Yoga. Jurnal Olahraga Prestasi. 2015;11(2):78.

11. Gudawati L, Muhlisin A. Perbedaan Tingkat Insomnia Lansia Sebelum dan Sesudah Senam Yoga di Posyandu Lansia Desa Blulukan, Kecamatan Colomadu, Kabupaten Karanganyar. Berita Ilmu Keperawatan. 2012;5(2):82-92.

12. Grace PH, Meryana P, Pantouw JG. Sleep Quality Before And After Yoga Exercises In Elderly At Posyandu Lansia Yuswo Widodo Surabaya. Journal of Widya Medika Junior. 2020;2(2):130137.

13. Bankar MA, Chaudhari SK, Chaudhari KD. Impact of Long Term Yoga Practice on Sleep Quality and Quality of Life in the Elderly. Journal of Ayurveda Integrative Medicine. 2013;4(1):28-32.
14. Varsha V. Yoga : A Way to Lead Good Quality of Life among Elderly. International Journal of Physiology, Nutrition and Physical Education. 2018;3(2):781-783.

15. Hegde A, Metri K, Chwadhary P, Babu N, Nagendra HR. Effects of Yoga on Cardiac Health Sleep Quality, Mental Health and Quality of Life of Elderly Individuals with Chronic Ailments. Voice Research. 2017;6(1):1-5.

16. Halpern J, Cohen M, Kennedy G, Reece J, Cahan C, Baharav A. Yoga for Improving Sleep Quality and Quality of Life of Older Adults. Alternative Therapies. 2016;20(3): 37-46.

17. R Vaezi A, Dehghani Tafti A, Behzadi Goodari S, Bidaki R. Effect of Yoga on Memory in Elderly Women. Elderly Health Journal. 2020;6(1):3-8.

18. Hishikawa N, Takahashi Y, Fukui Y, et al. Yoga-plus Exercise Mix Promotes Cognitive, Affective, and Physical Functions in Elderly People. Neurological Research. 2019;41(11):1001-1007.

19. Hariprasad VR, Koparde V, Sivakumar PT, et al. Randomized Clinical Trial of Yoga-based Intervention in Residents from Elderly Homes: Effects on Cognitive Function. Indian Journal of Psychiatry. 2013;55(7):357-363.

20. Jagannathan A, Raghuram N, Talwadkar S. Effect of Trataka on Cognitive Functions in the Elderly. International Journal of Yoga. 2014;7(2):96-103.

21. Darma PE, Yanti N, Eka Rosiani P, Rini Damayanti MS. Pengaruh Dharmagita terhadap Fungsi Kognitif Lansia di Banjar Abasan. Nurscope. 2016;2(3):1-8.

22. Afonso RF, Balardin JB, Lazar S, et al. Greater Cortical Thickness in Elderly Female Yoga Practitioners. Frontiers in Aging Neuroscience. 2017;9:1-6. 
23. Hariprasad VR, Varambally S, Shivakumar V, Kalmady SV, Venkatasubramanian G, Gangadhar BN. Yoga Increases the Volume of the Hippocampus in Elderly Subjects. Indian Journal of Psychiatry. 2013;55:1-6.

24. Khasanah K, Hidayati W. Kualitas Tidur Lansia Balai Rehabilitasi Sosial Mandiri Semarang. Journal Nursing Studies. 2012;1(1):194.
25. Silvanasari IA. Faktor-Faktor yang Berhubungan dengan Kualitas Tidur yang Buruk pada Lansia di Desa Wonojati Kecamatan Jenggawah Kabupaten Jember. Published online 2012:27.

26. Morrison JH, Baxter MG. The Ageing Cortical Synapse: Hallmarks and Implications for Cognitive Decline. Nature Reviews Neuroscience. 2012;13:240. 